\title{
An international industry perspective of tourism to post-apartheid South Africa: implications for marketing management
}

\author{
Mike Bendixen, Denis Cronson \& Russell Abratt* \\ Graduate School of Business Administration, University of the Witwatersrand, Johannesburg, P.O. Box 98, Wits, 2050 \\ Republic of South Africa
}

Received May 1996

\begin{abstract}
South Africa is now a democratic state and is being accepted in the community of nations. It has been shown that tourism can make a significant contribution to the development of this country by providing employment, contributing to foreign exchange earnings and by increased economic activity. The aim of this study was to establish the current perceptions of foreign tourist-industry representatives regarding South Africa as a tourist destination. The perceptions of 81 international travel-industry representatives were examined. The results show that South African tourism reflects a multidimentional problem. These factors need to be addressed in order for South Africa to have a vibrant and sustainable tourism industry.
\end{abstract}

\begin{abstract}
Suid-Afrika is nou ' $n$ demokratiese staat en word as deel van die gemeenskap van volke aanvaar. Toerisme kan ' $n$ betekenisvolle bydrae lewer tot die ontwikkeling van hierdie land deur middel van werksverskaffing, die verdienste van buitelandse valuta en verhoogde ekonomiese aktiwiteit. Die doel van hierdie studie was om die persepsies van buitelandse toerisme-industrieverteenwoordigers aangaande Suid-Afrika as ' $n$ toeristebestemming te bepaal. Die persepsies van 81 internasionale toerisme-industrieverteenwoordigers is ondersoek. Die resultate dui daarop dat Suid-Afrikaanse toerisme ' $n$ multidimensionele probleem reflekteer. Hierdie faktore behoort aangespreek te word om Suid-Afrika in staat te stel om op die lang termyn ' $n$ dinamiese toerisme-industrie daar te stel.
\end{abstract}

*Author to whom correspondence should be addressed.

\section{Introduction}

The tourism industry is integral to many developing countries, having the capacity to provide substantial employment, a significant contribution to foreign exchange earnings and increased economic activity in general. International tourism in 1994 directly employed more than 127 million people and generated direct and indirect employment for more than 200 million people or one of every nine workers worldwide (Gatty, 1993). The industry in South Africa is fourth in foreign exchange earnings, at R10 billion, accounting for less than 3\% of gross national product (Caras et al., 1993). The average annual growth rate of the global tourism industry over the past three decades has been $6 \%$ compared with a figure of only $2.5 \%$ for South Africa (Botha, 1993). In 1993, only 620000 overseas tourists visited South Africa, representing a mere $0.25 \%$ of the world's tourism market (Satour, 1994). In addition, South African tourism employs only one in every seventy workers (De Vaal, 1994).

South Africa is now a democratic state and is being accepted by the community of nations. This emergence as a potential model of managed reform has captured the imagination of the governments of all nations and the keen interest of the world media. Given the importance of international tourism in bringing about economic, social and cultural advancement, the aim of this research was to establish current perceptions, attitudes and orientations of foreign tourist-industry representatives regarding post-apartheid South Africa as a tourist destination.

\section{Literature review}

Tourism is not yet underpinned by a strong conceptual and theoretical base. Much of the published work is being carried out by those with a transient interest in tourism (Pearce, 1987). The need for the effective application of management techniques, the development of marketing plans and the effective implementation of marketing strategy is well recognized in the tourism industry (Go, Milne \& Whittles, 1992; Hawes, Taylor \& Hampe, 1991; Burke \& Lindblom, 1989). Traditional planning models and marketing planning processes have been adapted for the tourism industry. These conceptual models can form the basis for marketing planning for all the parties involved in the tourism industry (Heath \& Wall, 1992; Papadopoulos, 1989; Perdue \& Pitegoff, 1990). Mowen (1988) identifies three interactive perspectives of consumer purchase behaviour: the decision-making per spective, the experiential perspective and the behaviouralinfluence perspective.

Satour has conducted two studies on international marketing of South Africa as a tourist destination. The first was in 1991 and the second in 1995 (SATour, 1991 and 1995). The 1991 study dealt with workshops held in Europe and the United States of America. The 1995 study was conducted among stakeholders in the United States and Canada. Both studies highlighted a number of concerns or constraints. These included the personal safety of tourists in South Africa, inadequate facilities, as well as the lack of promotional material that reflects the new South Africa. They also clearly identified South Africa as having great potential as a tourism destination.

\section{Proposition development}

Consumers engage in a series of problem-solving tasks when faced with a range of alternatives. In the context of tourism, awareness or interest is created through the development of a desire to travel to accomplish one of the major travel motivators: desire for holiday/recreation, business needs, need to visit with friends or relatives (Yuan \& McDonald, 1990; Witt, Brooke \& Buckley, 1991). There is, however, considerable evidence to show a correlation between a decreasing rate of influx of tourists to a destination and an increased actual level 
interactive experiences (Krippendorf, 1982; Schwaninger, 1984).

In certain instances consumers make purchases to create feelings, experiences and emotions rather than to solve problems. The decision-making perspective in isolation is deficient due to an under emphasis of important consumption phenomena such as recreational leisure activities and actions taken for emotional reasons (Holbrook \& Hirschman, 1982). One of the best known and most frequently employed typecasting approaches classifies people as either introverts or extroverts. A very similar classification, with more application to the understanding of behavioural influences on tourist perceptions, categorizes people as either psychocentrics or allocentrics. Travel behaviour of these two categories of people differ significantly (Plog, 1981). Psychocentrics prefer the familiar in travel destinations and like commonplace activities and travel destinations. Allocentrics prefer low level or nontourist areas. They enjoy the sense of discovering in new ex periences before others have visited the destination. We can thus formulate the following propositions:

The willingness to visit is created by the current politica meaningfulness of South Africa as an uplifting example of political reform.

The psychological factors that influence the travel decisionmaker consist of both internal and social forces (Mayo \& Jarvis, 1981). The internal forces referred to here are concepts such as learning, personality, attitudes and motives. The social forces include reference groups, social class, role and family influences, culture and subculture particular to the individual. The central problem of consumer behaviour is choice (Taylor, 1974). In the context of tourism, the outcome of the travel decision can only be made after considerable energy and valuable time have been expended, not to mention the economic costs involved. Uncertainty about the consequences of a choice can be dealt with by reducing the amount at stake or putting off the choice (Taylor, 1974). Among the factors which are at stake in the travel decision are: money, time, energy, personal safety and psychological stress. The following three propositions can thus be formulated:

\section{Expense}

Notwithstanding the anxiety created in South Africa by the deterioration in its currency's exchange rate, this favourable differential has not altered the perception that the South African excursion is an expensive exercise.

\section{Value}

Determinants of economic attractiveness include costs, convenience, service quality and dependability. In this respect South Africa is perceived to offer a value-for-money tourism product, which offsets the perceived or actual costs associated with the long-haul tour.

\section{Distance deters}

The longhaul nature of the South African tourism product is a perceived inconvenience and hence a deterrent to potential visitors.

In some instances, consumers act in response to environmental pressures. An example is the global trend towards ecologically oriented tourism or 'eco-tourism' which has made the South African excursion more viable. Trends indicate that an increasing amount of tourists are seeking more nature-

\section{Wildlife and beauty}

South Africa's principle tourism asset, its natural endowment in fauna, flora and scenery, is a key perceived attraction for potential tourists.

\section{Out of Africa}

There is a perception among international tourists that South Africa is similar to some other states in Africa in terms of natural and man-made human disasters, subsistence and the possession of minimal infrastructure.

\section{Eco-tourism}

This proposition asserts that the global trend towards ecologically oriented tourism or 'eco-tourism' is the basis for an improved perception of South Africa as a viable excursion.

The success of travel agents depend on their superior access to information and specialist knowledge of markets and conditions. Such access enables this specialist to convey information, subjective opinion and motivating statements regarding a destination to the potential tourist, which may alter the tourist's perception of a destination and hence judgement of the tourism product (Moheswaran \& Sternthal, 1990). Exchanges which take place between the tourist and providers of products in the tourist destination itself are pertinent (Geva \& Goldman, 1989). Stereotypes are formed by visiting tourists and disseminated through inter-tourist communication where they become a further force in the creation or alteration of perceptions which potential tourists hold towards a target destination (Netlekoven, 1979). The following three propositions can be formulated:

\section{Perceived infrastructural deficiencies}

While the specific individual requirements of tourists may differ, common to all of them is the necessity for a basic set of tourism infrastructural and quality-based attributes. This proposition implies that there is a perceived deficiency in the tourism support infrastructure present in the South African tourism product. 


\section{Risk and travel specialists : information cures uncertainty}

This proposition asserts that their superior knowledge of destinations and conditions make tourism specialists (travel agents and tour operators) central figures in information search. This proposition claims that the apparent credibility of the specialist plays a substantial role in directly influencing this travel decision.

\section{Media exposure - pros and cons}

The central role that the media plays in the creation of perceptions regarding a tourist destination is unmistakable. This proposition demonstrates the dual potential of the media entity.

\section{Methodology}

It was the objective of this study to research the perceptions of the international tourism service industry. Travel agents, tour operators, the travel media, industry representatives, members of tourism agencies and travel boards were interviewed.

\section{Sample}

A total of 400 international tourism industry participants were covered through the use of a postal-return questionnaire distributed at an international travel-industry symposium held in Durban, South Africa in May 1994.

\section{Instrument}

The initial phase of the research comprised in-depth interviews with a number of experts in the tourism industry. Representation from the hotel, airline, tourism-marketing and consulting, banking and foreign-exchange industries was obtained. In addition, consultation with the South African Tourism Board (Satour), the Association of South African Travel Agents (ASATA), senior representatives from the ministry of tourism and the parliamentary standing committee on tourism was accomplished. The purpose of these interviews was firstly, to consolidate the theoretical frameworks presented in the literature review. Secondly, to identify the critical success factors pertaining to the tourism industry and their intrinsic relationship with tourist perceptions in South Africa. Thirdly, to gain an appreciation of the general and competitive environment within which participants in the tourism industry operate. Finally, the interviews enabled the elaboration of key constructs for integration into the research instrument.

The questionnaire contained three sections. The first comprised demographic details, the second examined the differences existing in the perceptions between South Africa and its competitor long-haul destinations. The last section consisted of 29 statements derived from the propositions and the initial in-depth interviews. Respondents were asked to rate their extent of agreement with these statements using a five-point Likert Scale.

\section{Data analysis}

The responses were captured using a spread sheet utilizing Microsoft Excel. The resulting data was then analysed using the Statistica and Number Cruncher Statistical System
(NCSS) packages using decriptive statistics, correspondence analysis, and factor analysis.

\section{Results}

\section{Respondents}

Altogether 81 useable responses were received representing a $20.5 \%$ response rate. The respondents represented 17 countries: six European countries (37.1\% of respondents); the United States of America and Canada (24.4\%); the United Kingdom, Australia and New Zealand (6.4\%); four African countries $(8.7 \%)$ while the remainder represented Malaysia and Chile. All the major South African tourist source markets were represented in the distribution.

While $35.1 \%$ of the sample were visiting South Africa for the first time, the remainder had prior experience of the destination.The respondents represented all industry sectors: tour operators represented $59 \%$ of the sample, $16 \%$ were travel agents, $17 \%$ represented the travel media and the remaining $8 \%$ were tourism board representatives.

\section{Statement evaluation}

The matrix of frequencies of response to the 29 constructs on the five-point Likert Scale was subjected to correspondence analysis. Correspondence analysis was used to rescale this data through an assessment of the Euclidean distance between scale points on the first two standard axes. These distances were then used to recreate the interval scale ranging from 1 to 5. This technique enabled statistical manipulation and valid statistical interpretation of inherently ordinal data by converting it into interval data (Bendixen \& Sandler, 1995). The results of this rescaling are presented in Table 1.

The rescaled mean ratings of the 29 statement are presented in Table 2.

The rescaled data was then subjected to principal component factor analysis. A six-factor solution was chosen as all these factors had eigenvalues in excess of unity and the six factor solution was readily interpretable. These six factors explained $55.8 \%$ of the variance in the rescaled data, and hence offered a parsimonious solution. The varimax rotated factor loadings are presented in Table 3 .

\section{Naming of the factors}

Factor 1

South Africa is an affordable and diverse eco-tourism destination. The statements 'scenery', 'wildlife', 'variety' and 'attractive foreign exchange' all load onto this factor. They allude to a strong eco-tourism product with a diversified

Table 1 Rescaling of five-point Likert Scale to interval scale: tourism industry

\begin{tabular}{lcccc}
\hline Likert Scale & $\begin{array}{c}\text { Ist axis } \\
\text { standard } \\
\text { co-ordinate }\end{array}$ & $\begin{array}{c}\text { 2nd axis } \\
\text { standard } \\
\text { co-ordinate }\end{array}$ & $\begin{array}{c}\text { Euclidean } \\
\text { distance to } \\
\text { next point }\end{array}$ & $\begin{array}{c}\text { Five-point } \\
\text { interval } \\
\text { scale }\end{array}$ \\
\hline Strongly disagree & 1.875 & -0.689 & 0.543 & 1.00 \\
Disagree & 1.339 & -0.602 & 2.341 & 1.31 \\
Neutral & 0.276 & 1.484 & 1.324 & 2.87 \\
Agree & -0.630 & 0.518 & 2.069 & 3.80 \\
Strongly agree & -1.107 & -1.523 & - & 5.00 \\
\hline
\end{tabular}




\begin{tabular}{|c|c|}
\hline Ci the them visiting that & $\begin{array}{l}\text { Mean } \\
\text { rating }\end{array}$ \\
\hline $\begin{array}{l}\text { The media focus on South Africa has discouraged many people from visiting that } \\
\text { country }\end{array}$ & 4.51 \\
\hline South Africa offers a wide range of holiday and recreational opportunities & 4.29 \\
\hline High standard accommodation is available in South Africa & 4.10 \\
\hline Scenic attractions are a majoc reason for people visiting South Africa & 4.03 \\
\hline Sowh Africa provides great variety as a tourist destination & 3.98 \\
\hline The foreign exchange rate makes it attractive to visit South Africa & 3.93 \\
\hline The high level of violence discourages tourists from visiting South Africa & 3.77 \\
\hline Sourh Africa offers an overall value-for-money tourism destination & 3.76 \\
\hline Atractive sporting facilities are available for tourists on holiday in South Africa & 3.70 \\
\hline Tourists do na visit South Africa because they fear for their safety & 3.69 \\
\hline South Africa offers sophisticated financial institutions to its business travellers & 3.54 \\
\hline An adequate global communications network via TV, radio and newspapers is present & 3.50 \\
\hline South Africa is an expensive travel destination & 3.44 \\
\hline Service quality is acceptable in South Africa & 3.40 \\
\hline South Africa may be an emotionally or spiritually meaningful destination for tourists & 3.39 \\
\hline South Africa's wildlife is the major reason for tourists visiting that country & 3.33 \\
\hline Sourh African locals go out of their way to be friendly and helpful to tourists & 3.32 \\
\hline The expense involved in the airfare to South Africa makes it an unattractive destination & 3.23 \\
\hline South Africa's major airports meet internationally accepted travel standards & 3.02 \\
\hline South Africa has adequate luxury coaches for tourists & 2.92 \\
\hline There is a well developed public transport system in South Africa & 2.85 \\
\hline South Africa provides adequate safety for its tourists & 2.80 \\
\hline People do not visit South Africa because they disapprove of its history of apartheid & 2.73 \\
\hline The inconvenience in travelling to South Africa makes it an unattractive destination & 2.65 \\
\hline Sourh Africa offers a vibrant night-life scene in its major cities & 2.55 \\
\hline $\begin{array}{l}\text { People are encouraged to visit South Africa as a result of the coverage received on } \\
\text { television, radio and in print media }\end{array}$ & 2.40 \\
\hline A bed and breakfast establishment in a black township would interest tourists & 2.40 \\
\hline $\begin{array}{l}\text { Tourists are worried about what people at home will think of them visiting South Africa } \\
\text { in terms of its history of apartheid }\end{array}$ & 1.89 \\
\hline $\begin{array}{l}\text { South Africa's tourism infrastructure and level of development is similar to other } \\
\text { African states }\end{array}$ & 1.80 \\
\hline
\end{tabular}

range of supporting attractions. A relatively weak local currency, which makes these national attributes highly affordable, adds to the positive tourist utility created by them. The average score for the statements loading onto this factor is 3.82 which implies a significant endorsement of the factor definition.

\section{Factor 2}

The South African tourism product appears to cater to the discerning tourist. The statements 'high standard accommodation', 'service quality' and 'luxury-tourist coaches' load onto this factor. These statements imply that key tourism attributes in South Africa conform to the more upmarket standard demanded by this fastidious tourist segment.

\section{Factor 3}

South Africa is depicted as a dangerous tourist destination. 'Tourists discouraged by violence', 'tourists fear for personal safety' and 'discouraged by media focus' load heavily onto this factor. These statements describe the significant impact of negative media coverage on the tourism equation. They also provide insight into the dependence of a tourism product on its global image that is projected by the media. The average statement score of 3.99 represents a strong affirmation of the prioritization of tourist safety by the tourism industry.

\section{Factor 4}

The South African travel decision presents a dilemma for the tourist. The statements 'perceived as expensive by tourists' and 'may be emotionally or spiritually meaningful for tourists' are both strongly tourist-orientated statements. They represent a dilemma in terms of the perceived material cost of the excursion and the intrinsic meaningfulness of the visit to a country undergoing fundamental social and political transformation. An average statement score of 3.41 for this factor 
Table 3 Rotated factor loadings

\begin{tabular}{|c|c|c|c|c|c|c|c|}
\hline Statement & Factor 1 & Factor 2 & Factor 3 & Factor 4 & Factor 5 & Factor 6 & Communality \\
\hline 1. Expensive & -0.0553 & +0.0663 & 0.1255 & +0.5557 & -0.2855 & -0.1415 & 0.4335 \\
\hline 2. Violence & -0.3263 & -0.0369 & -0.6752 & 0.2174 & -0.0023 & -0.2273 & 0.6626 \\
\hline 3. Adverse media focus & +0.1321 & +0.0244 & -0.7846 & +0.0935 & -0.1610 & -0.0781 & 0.6744 \\
\hline 4. Value for money & +0.4145 & +0.4708 & +0.2276 & +0.1703 & +0.0820 & 0.0715 & 0.5903 \\
\hline 5. Media coverage & +0.1080 & -0.0214 & +0.1326 & -0.1160 & +0.2283 & +0.7237 & 0.6190 \\
\hline 6. Fear for safety & -0.0885 & +0.1308 & -0.7041 & -0.2644 & +0.0173 & -0.0780 & 0.5808 \\
\hline 7. History of apartheid & -0.0480 & +0.2056 & +0.0217 & +0.3199 & -0.2789 & +0.7163 & 0.7383 \\
\hline 8. Foreign exchange & +0.6381 & +0.3462 & -0.1051 & +0.1235 & -0.2582 & +0.0954 & 0.6291 \\
\hline 9. Variety & +0.8248 & -0.1446 & +0.0845 & +0.1369 & +0.2435 & +0.0468 & 0.7722 \\
\hline 10. Scenery & +0.8262 & -0.2107 & +0.0517 & -0.0344 & +0.1145 & +0.0052 & 0.7440 \\
\hline 11. Inconvenient travel & -0.2829 & +0.0813 & +0.0549 & -0.2924 & -0.6338 & +0.2170 & 0.6239 \\
\hline 12. Airfare expense & -0.2238 & -0.1167 & -0.4198 & -0.2082 & -0.2335 & +0.3067 & 0.4319 \\
\hline 13. Home image & +0.1368 & +0.3174 & +0.1506 & +0.4514 & -0.0068 & +0.1914 & 0.3826 \\
\hline 14. Airport standards & -0.0652 & +0.5212 & +0.0921 & -0.2000 & +0.4513 & +0.2250 & 0.5787 \\
\hline 15. Africa standards & -0.0569 & +0.0934 & +0.1264 & -0.1601 & +0.6557 & +0.0336 & 0.4846 \\
\hline 16. Wildlife & +0.5904 & +0.1236 & -0.0098 & -0.4107 & -0.0312 & +0.2251 & 0.3881 \\
\hline 17. Meaningful & -0.0620 & +0.1585 & +0.1356 & +0.6998 & -0.0764 & +0.0518 & 0.5456 \\
\hline 18. Financial services & -0.2630 & +0.4950 & -0.0562 & +0.1043 & +0.1134 & +0.2766 & 0.6003 \\
\hline 19. Quality accommodation & -0.0090 & +0.7734 & -0.0050 & +0.0315 & -0.1379 & -0.0733 & 0.6237 \\
\hline 20. Service quality & -0.0201 & +0.8242 & -0.0301 & -0.0418 & +0.2299 & -0.1414 & 0.7369 \\
\hline 21. Public transpon & +0.1253 & +0.4064 & -0.0236 & +0.2245 & +0.1023 & +0.1251 & 0.4604 \\
\hline 22. Wide range & +0.2089 & +0.2132 & -0.1497 & +0.3301 & -0.1609 & +0.4402 & 0.4180 \\
\hline 23. Luxury coaches & +0.0718 & +0.7529 & +0.1899 & +0.0899 & +0.0144 & +0.0069 & 0.6164 \\
\hline 24. Sport facilities & +0.4441 & +0.3657 & +0.1671 & -0.0852 & -0.0199 & +0.1903 & 0.4028 \\
\hline 25. Vibrant nightlife & +0.1725 & +0.3052 & +0.3070 & +0.1268 & +0.2683 & +0.3371 & 0.4189 \\
\hline 26. Communications & +0.1865 & +0.2642 & +0.1023 & +0.2303 & +0.6238 & +0.1838 & 0.5910 \\
\hline 27. Friendly locals & +0.3960 & +0.1766 & +0.2351 & +0.0392 & +0.2945 & -0.0533 & 0.3344 \\
\hline 28. Tourist protection & +0.4973 & +0.3362 & +0.0089 & -0.2692 & +0.2479 & +0.0991 & 0.6787 \\
\hline 29. Township B \& B & +0.1408 & +0.1247 & +0.0093 & +0.3002 & +0.3627 & +0.4472 & 0.4571 \\
\hline
\end{tabular}

confirms agreement with the potential for tourist uncertainty regarding this travel decision.

\section{Factor 5}

The hardship of the South African excursion is a misconception. The statements inconvenience in travelling to South Africa makes it unaturactive' and 'South Africa is similar to other African states' load onto this factor. They imply substantial impediments to the travel decision. A potential ordeal in terms of distance and product standards is suggested. After reverse scoring statement 'inconvenience' (due to its negative loading relative to 'similar to African states' on varimax rotation), the low average statement score of 2.57 demonstrates disagreement with the implication of this definition. The true perception therefore is that the visit does not impose such burdens on the tourist and that these are an aged misconception.

\section{Factor 6}

South African tourism has shed the burden of apartheid, but... The statements which load onto this factor include 'tourists reject the South African visit because they disapprove of its history of apartheid' and 'people are encouraged by reports on South Africa in the media'. These statements vividly introduce the perceptual imagery of the old and new South Africa. The average statement score of 2.57 demonstrates a general disagreement with these statements. South Africa has unequivocally thrown off the infamous mantle of apartheid but has replaced it with the dubious perceptual distinction of uncertainty and potential regression. That these attributes are the basis for uncertainty in the mind of the potential tourist is probable.

The factors were tested for internal reliability using the Cronbach alpha coefficient as a measurement. The scores ranging from 0.53 to 0.82 were considered within acceptable limits (Peterson, 1994). Table 4 presents a summary of the key elements of the factor analysis.

\section{Discussion}

The initial proposition accepted that the present status of the South African tourism industry illustrated the obvious effects of isolation, violence and political uncertainty. It was postulated however, that the current perceptual consciousness of international tourists regarding South Africa as a tourist 
Thbo 4 Factor analysis: intemational tourism incustry

\begin{tabular}{|c|c|c|c|c|}
\hline & Facior nume & Stinemein & $\begin{array}{l}\text { Rolated factur } \\
\text { Jouding }\end{array}$ & $\begin{array}{l}\text { Crombach alpha } \\
\text { (factir ave) }\end{array}$ \\
\hline \multirow[t]{4}{*}{1.} & Sourth Africa is an & 10. Scenery & 0.83 & 0.82 \\
\hline & forduble und & 9. Vuriety & 0.81 & $(3.82)$ \\
\hline & diverte ecchtourism & 6. Auractive foreig exchunge & 0.64 & - \\
\hline & destiminion & 16. Wildafe & 0.59 & - \\
\hline \multirow[t]{3}{*}{2.} & The South Africu lournem procher & 20. High stumderd accommodinion & 0.82 & 0.80 \\
\hline & caters 20 the diecernme rourist & 19. Accepulate service quality & 0.77 & $(3.48)$ \\
\hline & m well & 23. Adequate lurury icurist coacties & 0.75 & - \\
\hline \multirow[t]{3}{*}{3} & Scurth Africen is depicted & 3. Mediu focus discourages tourism to SA & 0.78 & - \\
\hline & as a dunperous toursom & 6. Fere for personal sufery & 0.70 & (3.99) \\
\hline & detinausu & 2. Violence & 0.68 & - \\
\hline \multirow[t]{3}{*}{4.} & The Sourth Africen tranel & 17. SA resil emoucandly or spiritually & 0.70 & - \\
\hline & Decinacon presems a dilemana & mexningful & - & 0.55 \\
\hline & for the tourist & 1. Percerved as expensive & 0.56 & $(3.4)$ \\
\hline \multirow[t]{3}{*}{5.} & The hardithup of the Sourth Africas & 15. SA sumiler to Africa stundards & 0.66 & - \\
\hline & excursiom is a misconception & 11. Inconveniem to travel to $S A$ & 0.63 & 0.55 \\
\hline & & & & $(2.57)$ \\
\hline \multirow[t]{2}{*}{6.} & Sarth African tacrism tos shed & 5. Medin coverye encourages visin & 0.72 & 0.53 \\
\hline & the turdea of apurtheid tor ... & 7. Histary of aperthesd prevents visit & 0.72 & $(2.57)$ \\
\hline
\end{tabular}

desunation transcended these oven issues and refkected a multidimensional problem.

Predictatly: the research identified the elements of percerved violence and political volatility as substantial impedimems of tourism to South Africa. The first two propositions are thus accepted. The combination of tourist uscertainty and fear for personal safery was narrowed by the anxieties of the international toursm industry with respect to these factors. Both the industry and the staie will have to correct this untenable situation.

Comersely. the central strength of the South African tour1sm product was unequivocally identified as its eco-tourism atractions. which confirms propositions seven and nine. In addition, the international industry appraisal reflected on its ability to cater, where necessary. to the upmarket needs of the more discerning tourist. Thus proposition ten must be rejecied. Imponanty. South Africa's image as a typical African state has been superceded by an awareness of its advanced level of development, leading to the rejection of proposition eighx.

The potential for the existence of a dilemma in the mind of the tourist, with respect to the perceived worth and cost of this excursion. was initially identified by the respondents. Proposition four is strungly supponed. A reconciliation of these economic atuributes was demonstrated in their indication of percenved value in the South Afncan travel expenence accepung propostion five, by virue of its current political meaningfulness. thus also accepting proposition three. The current meaningfulness of the immediate post-apartheid era. while certainly valuable to the tourism industry, is an unsustainable advantage. The phase may have a finite duration, subsequent to which the truly tangible aspects of the South African tourism product will be the sole evaluating criteria.
The respondents dismissed proposition six. the long-haul distance characteristic as a definitive physical harrier. The media was identified as a central influence in the formulation and modification of perceptions on tourism to South Africa. Efforts at promoting tourism to that destination are strongly influenced by the tone of the international media. which convey much of the persuasive content of the information presented to potential tourists. Thus proposition twelve is accepted.

The socio-political reform which has taken place in South Africa was widely recognized and lauded by the survey respondents. This reality identifies a challenge confronting the tourism industry in South Africa, namely the depoliticization of the external image of that country. The central role of travel specialists in this information-conversion process was identified, leading to the acceptance of proposition eleven.

The realization of the goal of a globally competitive, vibrant and sustainable tourism industry depends on the interaction of a number of macroeconomic. socio-cultural, political and environmental variables. This study has identified many of the critical factors which need to be addressed in order to contribute towards an effective-strategic alignment of the tourism industry in post-apartheid South Africa.

\section{Implications for marketing managements}

The marketing planning implications ot the findings of this study should be based on attempts to reduce the high levels of uncertainty in the mind of the tourist. both during the decision-making process and nost purchase. As far as promotion strategy is concerned, the development of interpersonal relationships between the specialist and the potential tourist are essential. Personal recommendations and references to previous tourists to South Africa should be encouraged. 
It is essential for all the participants in the tourism industry, the government, the tourism authorities and travel agents, to promote political stability and encourage the police to reduce the levels of violence.

South Africa will have to improve its tourism product. The supporting infrastructure underpinning tourism is essential. The development and application of a countrywide standard and rating system is needed, and an emphasis on superior service quality is recommended. Training and development of hospitality and allied industry personnel is paramount.

The prioritization of tourism requires a definitive effort on the part of the government to make tourism one of its primary industries. Intra-industry alignment is also a necessity for sound co-ordinated marketing planning. Tour operators, travel agents, the tourism authorities, the airlines and hotel groups should interact synergistically to create common tourism objectives.

The ability to provide the potential tourist with unbiased information on which to make informed travel decisions, as well as providing the trade, regional bodies and planning authorities with information on which to base development decisions is a key requirement of a functional tourism industry. In this regard, the development of a marketing information system that will provide relevant, timely and accessible information can be regarded as crucial to the effective functioning of the tourism industry.

Marketing management has a large role to play in the development of the required marketing information system, the integrated marketing communications needed and the improvement of the tourism product. Marketing can also provide a substantial input in the design and presentation of marketing, sales and customer care programmes for the tourism industry. What South Africa needs is a comprehensive tourism marketing plan, co-ordinated by the ministry of tourism, with participation by all the role players.

\section{Acknowledgement}

The authors thank Marius Leibold for his constructive suggestions and advice on an earlier draft of this article.

\section{References}

Bendixen, M.T. \& Sandler, M. 1995. 'Converting verbal scales to interval scales using correspondence analysis', Management $D y$ -

namics: Contemporary Research, 4: 31-49.

Botha, F. 1993.Opportunities for the tourist industry, Travel Conference.

Burke, J.F. \& Lindblom, L.A. 1989. 'Strategies for evaluating direct response tourism marketing', Journal of Travel Research, 28: 3337.

Caras, D., Saunders, G., Bird, J. \& Kleynhans, C. 1993. Tourism talk: a bulletinon tourism and its allied industries in Southern Africa. Johannesburg.

De Vaal, A. 1994. Tourism in South Africa: the way forward. National Tourism Forum Conference, Midrand, February.

Enders, W., Sandler, T. \& Parise, G.F. 1992. 'An econometric analysis of the umpact of terrorism on tourism", Kyklos, 45: 531-554.

Gatty, B. 1993. 'Worlds No.1 Employer', Hotel and Motel Management, 208:1-15.
Geva, A. \& Goldman, A. 1989. 'Changes in the perception of a service during its consumption: a case of organised tours', European Journal of Marketing, 23: 44-52.

Go, F., Milne, D. \& Whittles, L.J. 1992. 'Communities as destinations: a marketing taxonomy for the effective implementation of the tourism action plan', Journal of Travel Re search, 30: 31-37.

Goodrich, J.N. 1991. 'An American study of tourism marketing: impact of the Persian Gulf War", Journal of Travel Research, 3: 3741

Hasek, G. 1991. 'Miami faces a hospitality boycott', Hotel and Motel Management, 206: 25-37.

Hawes, D.K., Taylor, D.T. \& Hampe, E.D. 1991. 'Destination marketing by states', Journal of Travel Research, 30: 11-17.

Heath, E. \& Wall, G. 1992. Marketing tourism destinations, a strategic planning approach. New York: Wiley and Sons.

Holbrook, M.B. \& Hirschmann, E.C. 1982. 'The experiential aspects of consumption: consumer fantasies, feelings and fun', Journal of Consumer Research, 9: 132-140.

Krippendorf, J. 1982. 'Towards new tourism policies', Tourism Management, 3: 135-148.

Mayo, E.J. \& Jarvis, L.P. 1981. The psychology of leisure travel. Boston: CBI Publishing Company.

Moheswaran, D. \& Sternthal, B. 1990. 'The Effects of knowledge, motivation and type of message on ad processing and product judgements', Journal of Consumer Research, 17: 66-73.

Mowen, J.C. 1988. 'Beyond consumer decisionmaking', Journal of Consumer Marketing, 5: 15-25.

Netlekoven, L., 1979. Mechanics of intercultural interaction in tourism: passport to development? A joint World Bank-Unesco Study, De Kadt, E. Washington: Oxford University Press,

Papadopoulos, S.I. 1989. 'A conceptual tourism marketing planning model: Part 1', European Journal of Marketing. 23: 31-40.

Papadopoulos, S.I. 1992. 'Strategy development and implementation of tourism marketing plans: Part 2', European Journal of Marketing, 23: 37-47.

Pearce, D. 1987. Tourism today: a geographical analysis. Essex, England: Longman Scientific and Technical.

Perdue, R.R. \& Pitegoff, B.E. 1990. 'Methods of accountability research for destination marketing', Journal of Travel Research, 28 : 45-49.

Peterson, R.A. 1994. 'A meta-analysis of Cronbach's Coefficient Alpha', Journal of Consumer Research, 21, September: 381-391.

$\mathrm{Plog}, \mathrm{S}$., 1981. 'Why destination areas rise and fall in popularity'. In Mayo, E.J. \& Jarvis, L.P. The psychology of leisure travel. Boston: CBI Publishing Company.

Satour, 1995. International marketing of South Africa in North America. Pretoria.

Satour, 1994. International strategic focus and marketing plan, 1994-1996. Pretoria.

Satour, 1991. International marketing of South Africa as a tourist destination. Pretoria.

Schwaninger, M. 1984. 'Forecasting leisure and tourism', Tourism Management, 5: 250-257.

Taylor, J.W. 1974. 'The role of risk in consumer behavior', Journal of Marketing, 38: 54-60.

Witt, S.F., Brooke, M.Z. \& Buckley, P.J. 1991. The management of international tourism. New York: Routledge Press.

Yuan, S. \& McDonald, C. 1990. 'Motivational determinants of international pleasure time', Journal of Travel Research, 29: 42-44. 